\title{
Aids in physics: Design and development
}

\author{
Norfaridatul Akmar binti Hasim a *, Mohd Mustamam bin Abd Karim b , Nurulhuda binti Abd Rahman c \\ Faculty of Science and Mathematics, Universiti Pendidikan Sultan Idris. \\ Tanjong Malim, Perak Darul Ridzuan 35900, Malaysia \\ a akma@smart.edu.my, b mustamam@fsmt.upsi.edu.my, c nurulhuda@fsmt.upsi.edu.my \\ * Corresponding Author.
}

Received: 18 May 2020; Revised: 26 May 2020; Accepted: 2 June 2020

\begin{abstract}
Electricity is found to be a difficult topic to learn due to its abstract concepts. Research showed that games based learning using dioramas can help students to interest and enhance students' understanding in learning abstract Physics topics. As a result, PhyKER Games was developed in order to assist students in the learning of the Electricity circuit topic. ADDIE model (analysis, design, development, implementation and evaluation) as instructional design and develope of PhyKER Games. Dioramas were added in PhyKER Games to depict real scenes. The information delivery and the flow of content follow the ADDIE phases theory. It is hoped that the PhyKER Games would be able to assist students in the learning of Electricity circuit terms of concept understanding and motivation level.
\end{abstract}

Keywords: Dioramas; Electricity; Games-based learning (GBL); PhyKER Games

How to Cite: Hasim, N. A. B., Karim, M. M. B. A., \& Rahman, N. B. A. (2020). Aids in physics: Design and development. Momentum: Physics Education Journal, 4(2), 57-63. https://doi.org/10.21067/mpej.v4i2.4432

\section{Introduction}

Electricity was considered one of the most difficult and boring subjects (Alias \& Ibrahim, 2017; Halim et al., 2014). Previous studies Korganci et al. (2015) showed that this topic is difficult to learn because the concepts are abstract. Generally, some common misconceptions or problems faced by students in learning Electricity are: (1) students described all types of wire as being equal in electrical current (Jaakkola \& Nurmi, 2008); (2) they felt that the battery always provided the same current into the electrical circuit (Baser, 2006).

In order to overcome boredom and increase enjoyment (Blamire, 2010) and lack of understanding, a method of teaching that engages students should be implemented such as game-based learning (Kebritchi et al., 2010) because according to the Akademi Sains Malaysia (2015) also stated that teaching methods such as game-based learning can provide fun and encourage students to participate in teaching and learning Science and ultimately enable students to gain an understanding of the end of the lesson.

As a result, interesting game must be designed (Tan et al., 2012). According to Sudjana and Rivai (2011), the diorama is a mini three-dimensional scenery that aims to depict real scenes so that students feel fun and engaged in the learning process. In conclusion, this makes the issue of gamebased learning an interesting area to study. For basic game learning methods, a tool or game material is required first. Hence, this is the first study ever conducted related to diorama element in physics game-based learning in order to assist students in the learning of Electric circuit. 
Momentum: Physics Education Journal, 4 (2), 2020, 58

Norfaridatul Akmar binti Hasim, Mohd Mustamam bin Abd Karim, Nurulhuda binti Abd Rahman

\section{Method}

\section{Design and Development Methodology in Educational Games}

In the process of developing educational games, there are various approaches or models that can serve as a guide. The ADDIE model, developed by Rossett (1987), has five phases which is analysis, design, development, implementation and evaluation. For this study the ADDIE model has been modified to fit the concept of the PhyKER Games development. Three aspects to be added to the ADDIE model are the cooperation of various experts, leaners and teacher. Although the ADDIE Model was modified according to the needs and requirements of the PhyKER Games Game development, the researchers still maintained the five phases (Figure 1).

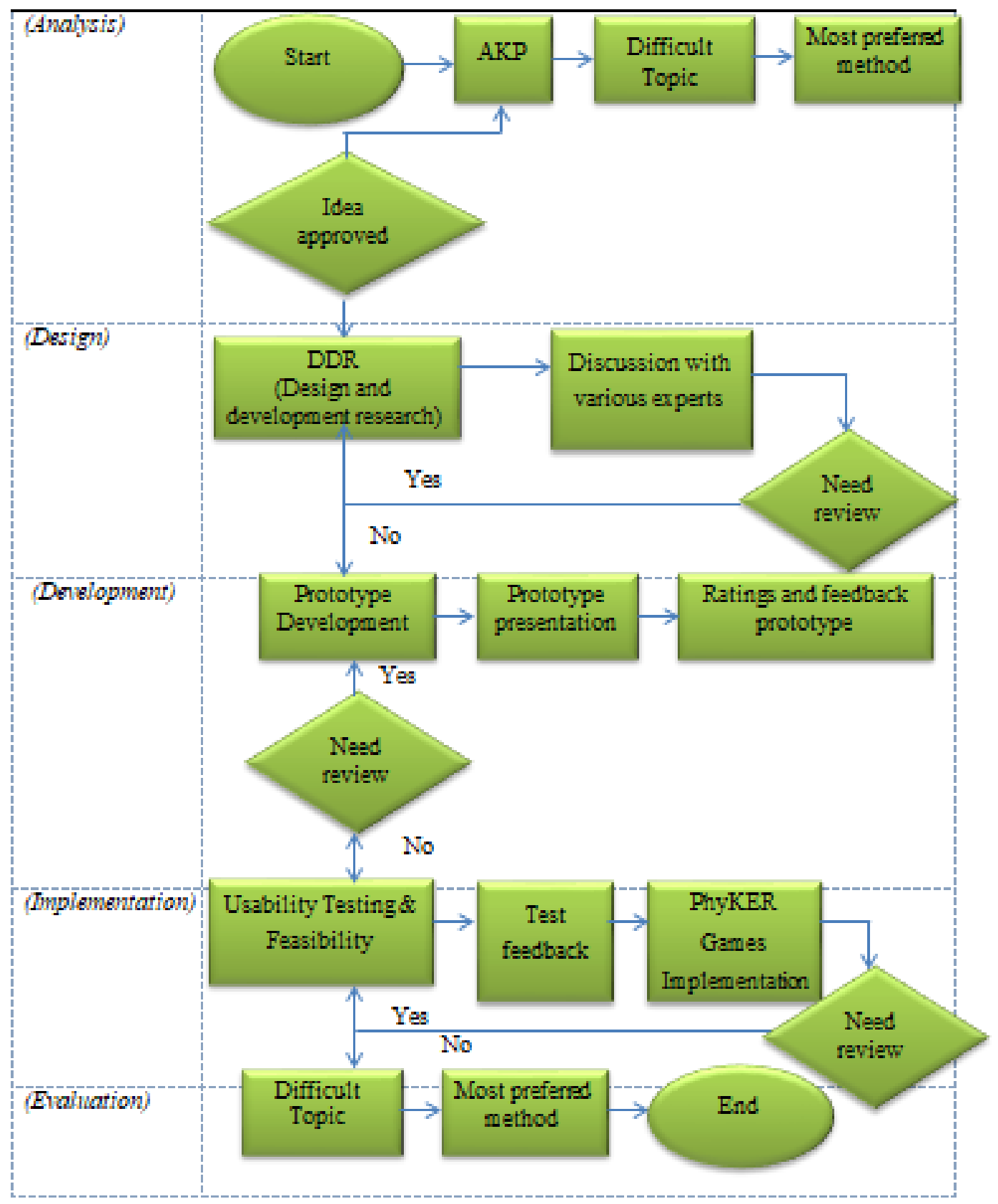

Figure 1. PhyKER Games Model adapted from the ADDIE Model

\section{Research design}

The study is a quasi-experiment by using a non-equivalent group pre-test post-test design. Samples in the treatment group using a PhyKER Games developed by the researcher. 
Momentum: Physics Education Journal, 4 (2), 2020, 59

Norfaridatul Akmar binti Hasim, Mohd Mustamam bin Abd Karim, Nurulhuda binti Abd Rahman

\section{Sample of the study}

Sixty ( 29 male and 31 female) form five students (17 years old) from one secondary schools were involved in the study. Two classes randomly selected as one treatment group and one control group. Refer Demographic Profile in Table 1.

Table 1. Demographics profile

\begin{tabular}{lccc}
\hline \multicolumn{1}{c}{ Information } & Control Group (5K) & Treatment Group (5F) & Total \\
\hline Student's Gender & 30 & 30 & 60 \\
Male & 15 & 14 & 29 \\
Female & 15 & 16 & 31 \\
Ratio Male: female & $1: 1$ & $1: 1.428$ & $1: 0.689$ \\
\hline
\end{tabular}

\section{PhyKER Games Development}

The goal in designing the proposed game was to optimize the benefits of a PhyKER Games in electricity circuit. In this game, the first part is that players have to strategize how they play to achieve goals when they are within the rules. The challenge that comes through the process of achieving the goal is limited by game rules and will make players feel fun during playing. Secondly is an interaction that combines learning content that involves individual electricity experimental and an amusement-based board game kit. In general, interaction means active action or relationship with each other (Dewan Bahasa dan Pustaka, 2005). Therefore, researchers formulate play designs that emphasize the need to balance the challenges in the game. Interactions in the game also involve players' actions and reactions when complying with rules.

\section{How to Play}

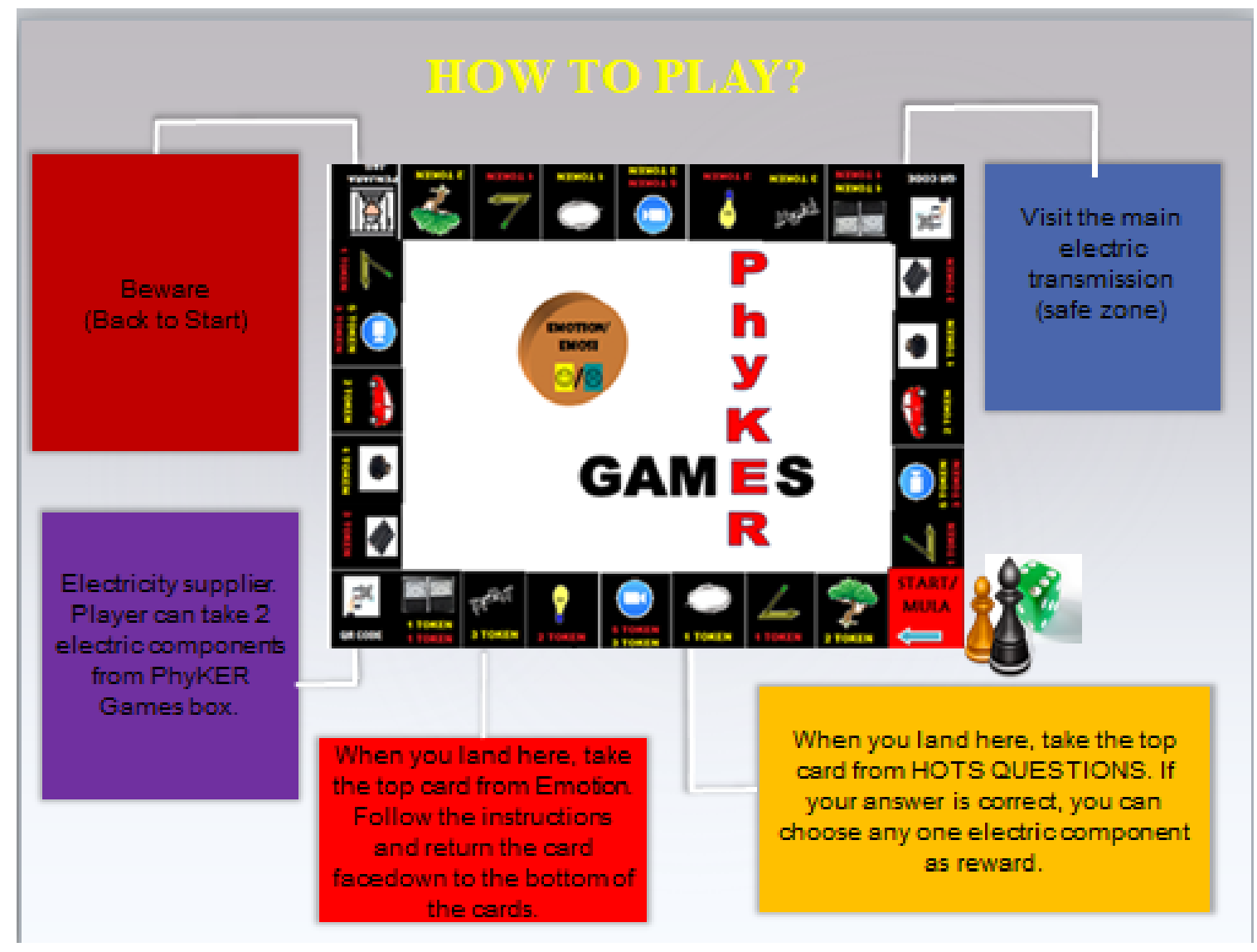

Figure 2. Regulation and challenges in PhyKER Games

Each player must throw the dice. The player with the highest number of dice starts to play. Both players place the player representative in the "START" box, then drop the dice and move the 
Momentum: Physics Education Journal, 4 (2), 2020, 60

Norfaridatul Akmar binti Hasim, Mohd Mustamam bin Abd Karim, Nurulhuda binti Abd Rahman

player toward the board according to the number of dice that have been thrown. Once he is done playing, it is your opponent's turn to continue the game. Two or more players can rest in the same compartment and at the same time can take a token bonus ( 15 yellow tokens and 15 red tokens) and issue an emotion card. Figure 2 show the regulation and challenges and Figure 3 shows the compartments that exist in PhyKER Games main board.

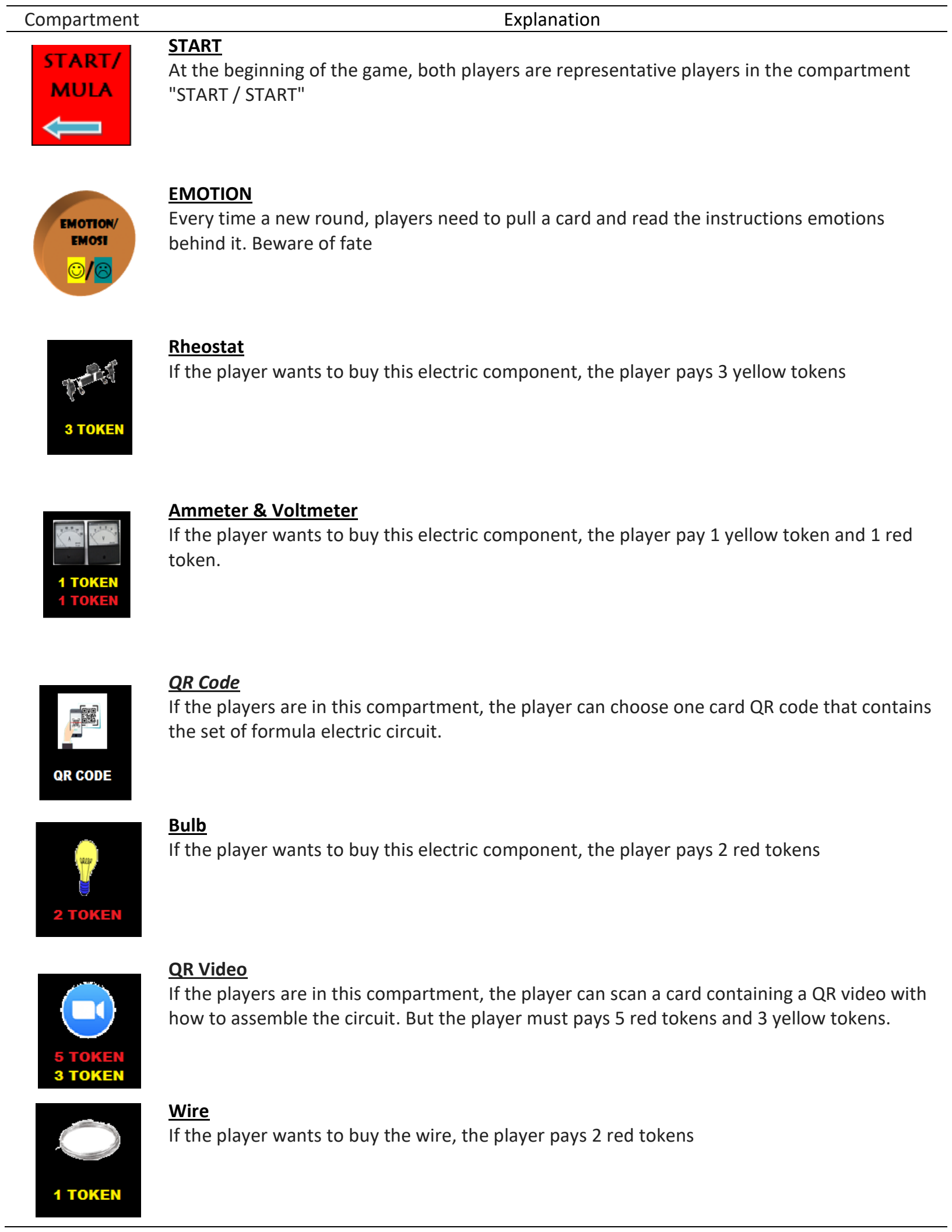


Momentum: Physics Education Journal, 4 (2), 2020, 61

Norfaridatul Akmar binti Hasim, Mohd Mustamam bin Abd Karim, Nurulhuda binti Abd Rahman

Compartment

Figure 3. The compartment in PhyKER Games main board

\section{Results and Discussion}

Figure 4 show the step that players need to complete the game which is start from thrown the dice. Then buy the diorama accessories and electronic component using red or yellow tokens. They must to complete both circuits (series and parallel) with plug and play at diorama board. According to Sudjana and Rivai (2011), dioramas can be categorized as real objects similar to the real world but resized on a smaller scale.
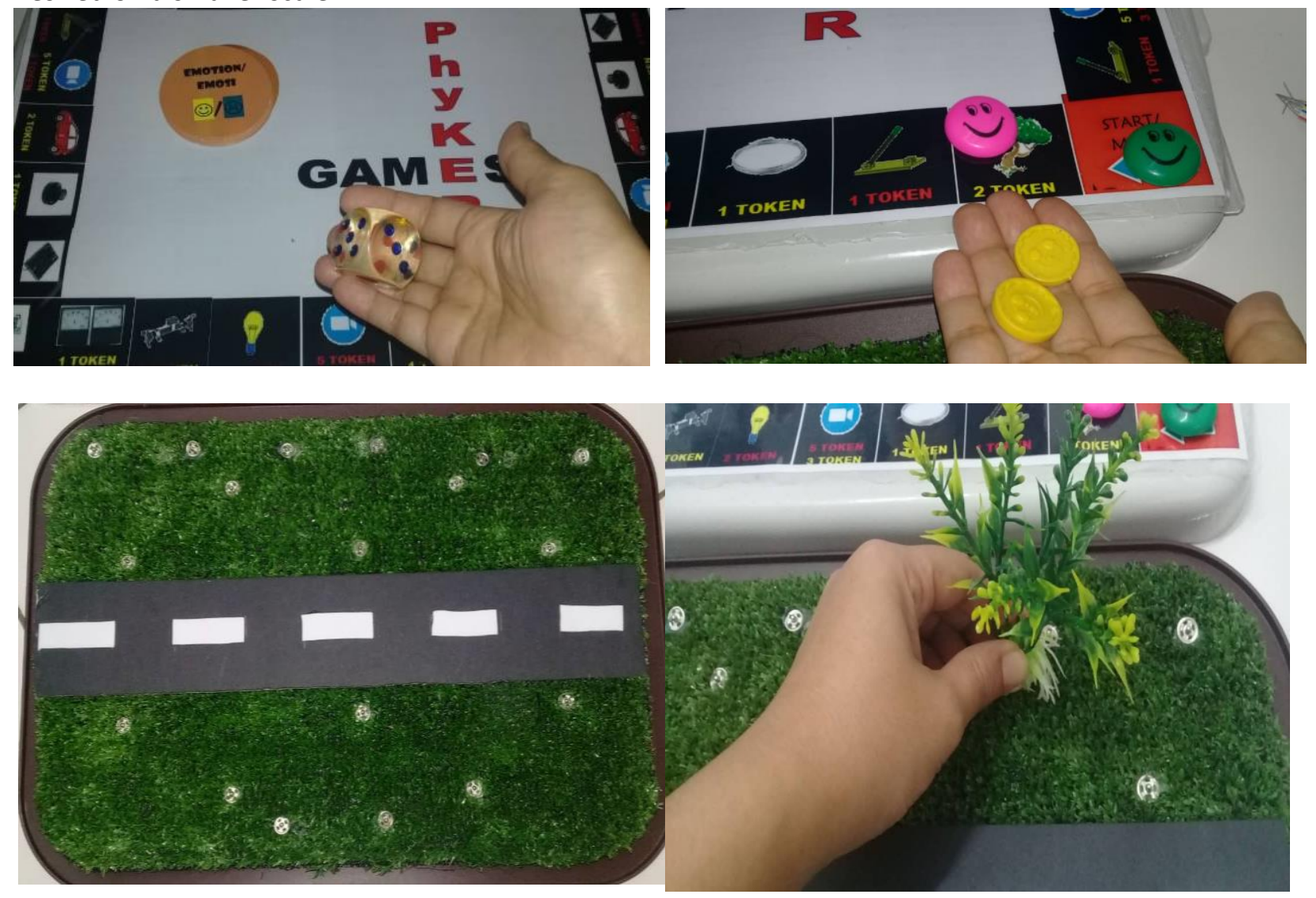

Figure 4. The step that players need to complete the game

The accessories diorama involved in PhyKER Games include trees, roads, cars and street lights. Figure 5 shows that the bulb will light up when players complete the circuit. The winner will receive a trophy-shaped key chain. 


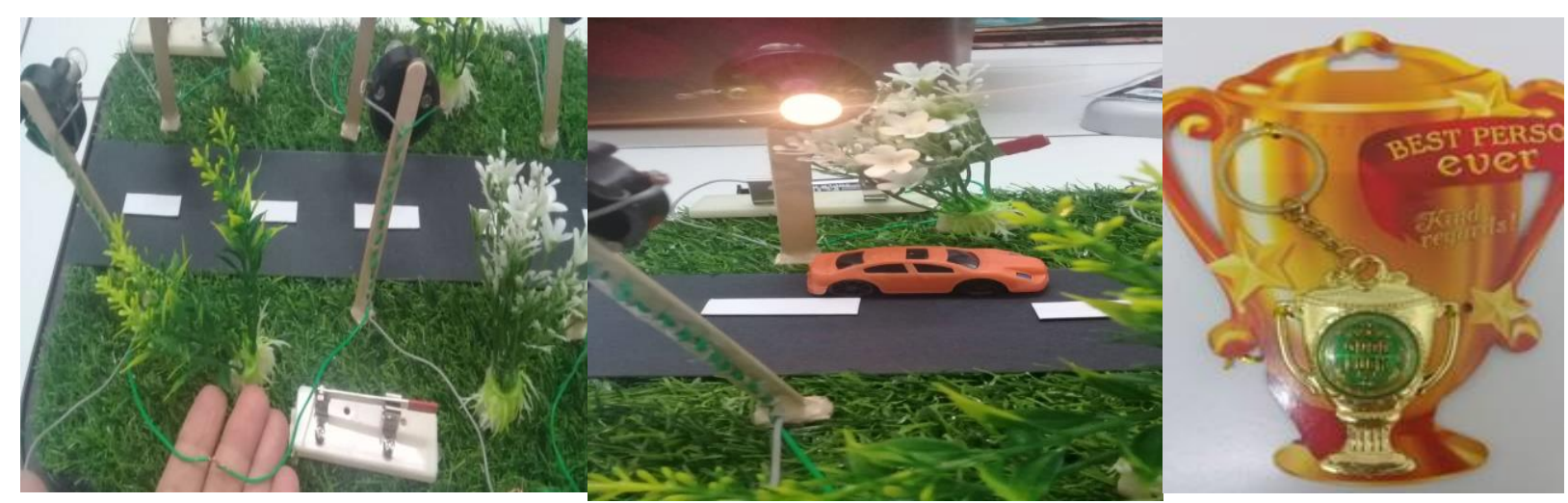

Figure 5. Final Result

\section{Conclusion}

PhyKER Games is developed by applying the ADDIE models that can serve as a guide. PhyKER Games implemented five phases of ADDIE so that students could generate their ideas from existing knowledge through their daily experiences. Elements of dioramas are used in the information delivery process so that students can have a different experience of learning in depict real scenes. The PhyKER Games is developed after months of effort, so it is hoped that it can improve students' understanding and motivation in the learning of Electricity. It is hoped that this study has not only developed a game even using the game will also have an impact in terms of increasing performance and motivate students during learning. Moreover, the implications could be used as a tool for teaching and learning and can also be used as a reference and training workshops for teachers.

\section{References}

Akademi Sains Malaysia. (2015). Penilaian pelaksanaan projek rintis pendidikan sains berasaskan amalan inkuiri (IBSE) di empat buah sekolah rendah di Daerah Hulu Langat. Akademi Sains Malaysia.

Alias, S. N., \& Ibrahim, F. (2017). Keberkesanan permainan pendidikan terhadap pembelajaran hukum Newton. Journal of Nusantara Studies (JONUS), 2(1), 71. https://doi.org/10.24200/jonus.vol2iss1pp71-85

Baser, M. (2006). Promoting conceptual change through active learning using open source software for physics simulations. Australasian Journal of Educational Technology, 22(3). https://doi.org/10.14742/ajet.1290

Blamire, R. (2010). Digital games for learning: Conclusions and recommendations from the IMAGINE project. European Schoolnet.

Dewan Bahasa dan Pustaka. (2005). Kamus dewan. Dewan Bahasa dan Pustaka Malaysia.

Halim, L., Yong, T. K., \& Meerah, T. S. M. (2014). Overcoming students' misconceptions on forces in equilibrium: An action research study. Creative Education, 05(11), 1032-1042. https://doi.org/10.4236/ce.2014.511117

Jaakkola, T., \& Nurmi, S. (2008). Fostering elementary school students' understanding of simple electricity by combining simulation and laboratory activities. Journal of Computer Assisted Learning, 24(4), 271-283. https://doi.org/10.1111/j.1365-2729.2007.00259.x

Kebritchi, M., Hirumi, A., \& Bai, H. (2010). The effects of modern mathematics computer games on mathematics achievement and class motivation. Computers \& Education, 55(2), 427-443. https://doi.org/10.1016/j.compedu.2010.02.007

Korganci, N., Miron, C., Dafinei, A., \& Antohe, S. (2015). The importance of inquiry-based learning on electric circuit models for conceptual understanding. Procedia-Social and Behavioral Sciences, 
Momentum: Physics Education Journal, 4 (2), 2020, 63

Norfaridatul Akmar binti Hasim, Mohd Mustamam bin Abd Karim, Nurulhuda binti Abd Rahman

191, 2463-2468. https://doi.org/10.1016/j.sbspro.2015.04.530

Rossett, A. (1987). Training needs assessment. Educational Technology.

Sudjana, N., \& Rivai, A. (2011). Media pengajaran. Sinar Baru Algensindo.

Tan, W. H., Neill, S., \& Johnston-Wilder, S. (2012). How do professionals' attitudes differ between what game-based learning could ideally achieve and what is usually achieved. International Journal of Game-Based Learning, 2(1), 1-15. https://doi.org/10.4018/ijgbl.2012010101 